\title{
Exploring Vocabulary Items in Malaysia Year 5 English Language Textbook (English Plus 1)
}

Noor Iylia Abu Bakar, Hanita Hanim Ismail

To Link this Article: http://dx.doi.org/10.6007/IJARBSS/v11-i12/11707

DOI:10.6007/IJARBSS/v11-i12/11707

Received: 14 October 2021, Revised: 16 November 2021, Accepted: 04 December 2021

Published Online: 25 December 2021

In-Text Citation: (Bakar \& Ismail, 2021)

To Cite this Article: Bakar, N. I. A., \& Ismail, H. H. (2021). Exploring Vocabulary Items in Malaysia Year 5 English Language Textbook (English Plus 1). International Journal of Academic Research in Business and Social Sciences, 11(12), 2299-2315.

Copyright: @ 2021 The Author(s)

Published by Human Resource Management Academic Research Society (www.hrmars.com)

This article is published under the Creative Commons Attribution (CC BY 4.0) license. Anyone may reproduce, distribute, translate and create derivative works of this article (for both commercial and non0-commercial purposes), subject to full attribution to the original publication and authors. The full terms of this license may be seen at: http://creativecommons.org/licences/by/4.0/legalcode

Vol. 11, No. 12, 2021, Pg. 2299- 2315

Full Terms \& Conditions of access and use can be found at http://hrmars.com/index.php/pages/detail/publication-ethics 


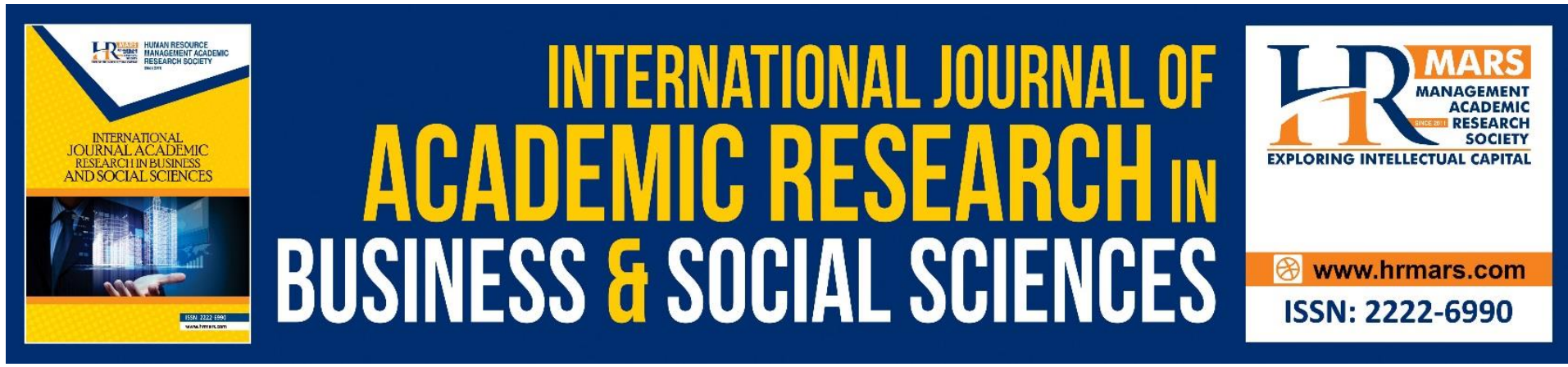

\title{
Exploring Vocabulary Items in Malaysia Year 5 English Language Textbook (English Plus 1)
}

\author{
Noor Iylia Abu Bakar ${ }^{1,2}$, Hanita Hanim Ismail ${ }^{2}$ \\ SJK(C) Lawan Kuda Baru, Gopeng, Perak, Malaysia ${ }^{1}$, Faculty of Education, Universiti \\ Kebangsaan Malaysia, Selangor, Malaysia. ${ }^{2}$ \\ Email: ii9354@gmail.com, hanitaismail@ukm.edu.my
}

\begin{abstract}
Many studies have shown the importance of vocabulary in learning a second language. However, only a few studies explored the presentation of vocabulary in Year 5 English textbook (English Plus 1). This study aims to explore teachers' evaluation of the new vocabulary in the textbook. This study employed a quantitative method. A total of 10 teachers from suburban and urban Chinese Type Primary School in Perak, Malaysia were selected using a convenience sampling technique. The questionnaires were adapted from Hussin, Nimehchisalem and Kalajahi (2015). The findings revealed that the textbook does an excellent job of presenting vocabulary. It was discovered that no particular approach was used to teach the new vocabulary. At the end of the textbook, there was no glossary of the new vocabulary. The findings have consequences for students and English language teachers. This paper is also meant to give teachers with ideas for to improve their approaches in teaching vocabulary and correcting inadequacies in the presentation of vocabulary in textbooks.
\end{abstract}

Keywords: English Language Textbook, Textbook Evaluation, Vocabulary Items, Young Learners, ESL.

\section{Introduction}

English is regarded as an international language. People around the world use English as a means of communication regardless of nationality and country. English is the most often used language in the working world, making it one of the most vital employability skills. The capacity to convey oneself fluently in both written and oral forms of language is critical for career advancement.

Realising the importance of mastering English language, Malaysian Ministry of Education (MOE) has introduced the Malaysian Education Blueprint (2013-2025) that aims to transform the education system. This transformation is important in helping students in Malaysia to excel in the language in order to be globally competitive. Under the Malaysian Education Blueprint (2013-2025), there are 11 shifts in transforming the education system. Since 2013, the Ministry of Education has opted to include Common European Framework of Reference for Languages (CEFR) into the English language curriculum, resulting in changes to the syllabus, assessment, and resources to correspond with the international reference set. This 
has resulted in the development of a new curriculum that emphasises student-centeredness and differentiated teaching. CEFR is developed by the Council of Europe as a guideline to standardise language proficiency. Its function as the 'comprehensive reference tool' has been recognised in Europe and other countries. Thus, it is suitable to be implemented in the educational curriculum in Malaysia as it is widely used and recognised at the international level. In Malaysia, the implementation of CEFR is aligned with the Cambridge-level English. The curriculum seeks to improve students' English language competence in order to fulfil their daily language demands, knowledge acquisition needs, and future employment requirements in a globalising world (Malaysian Education Blueprint 2013-2025, 2013). As its primary goal of learning and teaching English in Malaysia is to communicate fluently and accurately in the language, mastery of a broader breadth of vocabulary knowledge is crucial. The more expansive one's vocabulary, the more fluent and precise one's communication will be.

Aligning with CEFR, the Ministry of Education has replaced the previous local textbooks for Year 5 with English Plus 1 from Oxford University Press. English Plus1 is a foreign textbook that has been adapted to the education curriculum. The requirement for English proficiency is critical, and measures have been taken to develop pupils who utilise English in their everyday lives. English Plus 1 is a Cambridge-certified international textbook developed and edited by British linguists. Since 2021, it has been offered to Year 5 pupils as the primary textbook for teaching and learning English in Malaysian schools. Along with its skill-based integrated approach, the book seeks to enhance students' receptive and productive abilities, as well as their communication competence. Its profusion of connections to CEFR scales is one of the reasons it has been chosen as Malaysia's main English textbook for Year 5.

However, the audacious decision to execute it and to utilise foreign textbooks in Malaysian classrooms drew varied reactions from academics, parents, teachers, and associations (Sani, 2018). The introduction of the English Plus 1 as the national Year 5 English textbook has sparked debates among the teachers on how to introduce the content to the students. It is an international textbook that is being adopted and used in Malaysia. It focuses more on the international context and minimal local context has been added in the textbook.

Many studies have been conducted on the evaluation of foreign textbooks currently used in Malaysia especially secondary school (Goh \& Abdul Aziz, 2020; Shak et al., 2021; Abdul Rahim \& Daghigh, 2020) but few focusing on primary school foreign textbooks (Takal et al., 2021; James \& Aziz, 2020). Most of the study investigates teachers' and students' perception on using the foreign textbook and none of them evaluate the presentation of new vocabulary items in the textbook.

Vocabulary items are regarded as language building blocks (Schmitt, Schmitt \& Clapham, 2001) and as textbooks are the primary source of vocabulary learning, it is crucial to investigate how they are presented in Malaysian school textbooks. Thornbury (2002) once said, "without grammar very little can be conveyed, without vocabulary nothing can be conveyed. Consequently, it is essential to evaluate how new vocabulary items are presented in textbooks. The reason that spurred the selection of Year 5 English Plus 1 was that the layout and the content of the textbook are different from the foreign English textbooks that were used for Year 1 until Year 4 and the textbook is still very new. 
The focus of this study was to look further into the presentation of new vocabulary items in the Malaysian English Language Textbook for the sake of students' successful learning, based on the evaluations of a group of English language teachers who used a checklist designed specifically for this purpose. It is also intended to help English instructors assess the strengths and weaknesses of the distribution of new vocabulary items in textbooks. The findings may help teachers use suitable techniques in classroom activities to teach new vocabulary effectively.

\section{Research Objective}

This study aimed to investigate non-Chinese English teachers in sub-urban Chinese Primary School in Perak evaluation of the presentation of new vocabulary items.

\section{Research Questions}

1. How do the teachers evaluate the presentation of the new vocabulary items in Year 5 foreign textbook based on the checklist?

\section{Literature Review \\ Textbook's Roles in ESL Classroom}

There are five interrelated components in each educational system: students, teachers, materials, instructional techniques, and evaluation (Hussin et al., 2016). Textbooks are essential in the teaching-learning process. Textbooks, as students' principal source of contact with the language aside from instructor input, can give some indirect education for new teachers through the use of teacher's guides. In addition, textbooks are an important part of the curriculum. Richard (2001) claimed that textbooks serve as a foundation for most of the language input and practise that students get in the classroom.

Textbooks are the primary source of information for teachers and students. They can be thought of as the course's structure, recommending teachers on what and how to teach their students. They also serve as an essential source of direction for instructors, as it is difficult for them to develop suitable and relevant resources for their pupils. As a consequence, textbooks save teachers time and allow them to focus on teaching rather than the preparation of materials (Vavruv and Salema, 2013).

Apart from that, students who are committed to their studies and have an objective in mind prefer to use textbooks. Aside from the input offered by their teachers, textbooks are a primary source of contact they have with the language. As mentioned by Hemmi et al (2019) students can become less reliant on textbooks since they can utilise them to learn new things, review and check their own progress without relying solely on teachers.

\section{Importance of English Textbook in Teaching and Learning}

Riazi (2003) claimed that in the context of a second language school, the textbook is the second most significant component after the teacher's role. Moreover, Garinger (2001) stated that textbooks had a substantial impact on classroom language learning processes. According to Tomlinson (2011), a textbook is described as a book that provides the basic materials for a language learning course. Litz (2005) stated that teaching ESL programmes, textbooks have been viewed as the first approach in achieving the students' goals and needs. To fulfil the primary goals of learning a second language, instructors should choose textbooks that are acceptable for the criteria, teachers' and learners' circumstances, and their purposes and requirements. However, Ramzjoo (2010) claimed that most instructors do not have the 
freedom to select their textbooks in some kinds of cases. In addition, Abdelwahab (2013) argued that utilising a textbook in the school "can guarantee that students in various classrooms would acquire identical information and, as a result, may also be evaluated in the same way". Richards (2001) also emphasised the importance of textbooks with the assertion that while textbooks offer structure and a syllabus, learning may not have any benefit if the teaching course does not include textbooks.

An excellent English textbook may assist pupils in achieving their learning objectives or goals when studying English. An excellent textbook should be divided into two sections: general features and learning-teaching material. The first category is subdivided into five sections: syllabus and curriculum, methodology, learner appropriateness, physical and functional features, and additional resources. The second category includes general (task quality, cultural sensitivity, linguistic and situational realism), hearing, speaking, reading, writing, vocabulary, grammar, pronunciation, and activities (Nimehchisalem \& Mukundan, 2015).

\section{Purpose of Evaluation}

Lynch (1996) defined evaluation as the methodical collection of facts to make a judgement or conclusion. Textbook evaluation can result in a sound judgement on whether the offered materials and their importance in the syllabus are appropriate for the desired teaching technique (Littlejohn, 1998). According to Abhar (2017), textbook evaluation may assist teachers in recognising the information given in the books and, if required, revising and adapting the contents depending on the actual needs and requirements of the learners. The evaluation process and findings would illuminate many elements of teaching technique, such as the autonomy-inducing features of the materials and the primary role of the instructor and learners in language acquisition.

\section{Evaluation of Vocabulary}

Learners must be exposed to a significant quantity of information to acquire vocabulary in a second language (Webb \& Nation, 2017). Sun \& Yen Dang (2020) claimed that to maximise learning, the vocabulary in ESL textbooks should be carefully chosen so that students can grasp the contents while also paying attention to the terms that are most relevant to them.

\section{Rationale of Using the Checklist}

Most language experts agree that using checklists to evaluate textbooks is a great idea. Tomlinson (1998) promotes the application of this approach, stating that one of the most apparent sources of assistance in evaluating materials is the huge number of frameworks like checklists that are available to assist in the assessment of a textbook. Checklists are simple to use and have been deemed helpful for stakeholders, instructors, and pre-service teachers seeking practical information about a coursebook.

Textbook assessment may assist teachers and curriculum developers, and material creators in identifying and reflecting on textbook key aspects such as approach, content, activities and tasks, and supplemental resources, among others. 


\section{Methodology}

\section{Research Design}

The method of this research is descriptive. The information was obtained from two groups of teachers' evaluations on the presentation of new vocabulary items in the textbook using a modified checklist developed by (Hussin et al., 2015).

\section{The Evaluators}

The evaluators for this study were 10 of Year 5 teachers from a Chinese primary school in Perak, Malaysia, who had taught the textbook. The evaluators were non-Chinese female instructors aged 28 to 40 who did not know the fundamentals of Mandarin. Five instructors were from urban schools, while the remaining five were from Perak's sub-urban Chinese primary schools. They've been teaching English for more than five years. They were all bachelor's degree holders in Teaching English as a Second Language.

\section{Research Material}

The materials used for this study was English Plus 1, Year Five English textbook taught in primary schools in Malaysia.

\section{Research Instrument}

The adopted Checklist for Evaluating New Vocabulary Presentation in ELT Textbook (Mat Hussin et al., 2015) was used to collect data for this study. This checklist was adapted to suit the primary context and to know strategies that were used by the teachers to introduce the vocabulary in the class. The current checklist has 11 items on a 5-point Likert scale, with ' 0 ' indicating 'totally deficient,' ' 1 , bad,' '2, adequate,' '3, good,' and '4, exceptional' (Appendix 1). The 11 items examined the load of new words, the balance of simple and complex words, the distribution of vocabulary load across each chapter, the contextualization of new words, the recycling of new words, the presentation of new vocabulary, the topical nature of the vocabulary exercises, the new lexical of in each unit, the specific method to teach new vocabulary, the quality of the sentences and examples defining the new vocabulary. The checklist was chosen because it is adaptable, understandable, and tailored to the needs of the textbook's students.

\section{Research Procedures}

The checklist was uploaded on Telegram, and the evaluators were given detailed instructions on how to complete the online checklist (Google Form). The evaluators were given ample time to respond to each item separately. The checklists were gathered, and the replies of the evaluators were recorded into SPSS. The information was analysed in a descriptive manner.

\section{Findings and Discussion}

\section{Demographic results}

Table 1 presents the descriptive data for the demographic of the evaluators $(n=10)$, aged between 28 and 40 .

Evaluators 1,2,3,4 and 5 were from sub urban Chinese Primary School in Perak and evaluators $6,7,8,9$ and 10 were from urban Chinese Primary School in Perak. 
INTERNATIONAL JOURNAL OF ACADEMIC RESEARCH IN BUSINESS AND SOCIAL SCIENCES Vol. 11, No. 12, 2021, E-ISSN: 2222-6990 @ 2021 HRMARS

Table 1. Descriptive statistics results of the evaluators' demographic information

\begin{tabular}{|l|l|l|l|l|}
\hline Evaluator & Age & Level of education & Teaching Experience & School's Location \\
\hline 1 & 28 & BA & 4 & Suburban \\
\hline 2 & 30 & BA & 6 & Suburban \\
\hline 3 & 29 & BA & 5 & Suburban \\
\hline 4 & 30 & BA & 6 & Suburban \\
\hline 5 & 31 & BA & 7 & Suburban \\
\hline 6 & 31 & BA & 7 & Urban \\
\hline 7 & 35 & BA & 11 & Urban \\
\hline 8 & 34 & BA & 10 & Urban \\
\hline 9 & 39 & BA & 15 & Urban \\
\hline 10 & 32 & BA & 8 & Urban \\
\hline
\end{tabular}

According to the table, the evaluator' teaching experience ranged from 4 to 15 years, with an average of around eight years.

\section{Analysis of the criteria in the checklist}

This section summarises the evaluators' assessments of the textbook's quality based on their responses to each checklist item. 
Table 2. Results of the evaluation of vocabulary in Malaysian Year 5 English language textbook

\begin{tabular}{|c|c|c|c|c|c|c|c|c|c|c|c|}
\hline Criteria & E 1 & E2 & E3 & E4 & E5 & E6 & E7 & E8 & E9 & E10 & The average \\
\hline $\begin{array}{l}\text { The load (number of new } \\
\text { words in each lesson) is } \\
\text { appropriate to the } \\
\text { linguistic level of students. }\end{array}$ & 3 & 3 & 3 & 3 & 3 & 2 & 2 & 1 & 1 & 2 & 2.3 \\
\hline $\begin{array}{l}\text { There is balance of simple } \\
\text { and complex words. }\end{array}$ & 3 & 3 & 3 & 3 & 3 & 2 & 2 & 1 & 1 & 2 & 2.3 \\
\hline $\begin{array}{l}\text { Good distribution of } \\
\text { vocabulary load across } \\
\text { each chapter. }\end{array}$ & 4 & 3 & 4 & 3 & 4 & 3 & 3 & 4 & 3 & 4 & 3.5 \\
\hline $\begin{array}{l}\text { Few words are repeated } \\
\text { across the book for } \\
\text { delayed recall }\end{array}$ & 4 & 4 & 4 & 4 & 4 & 4 & 3 & 3 & 3 & 4 & 3.7 \\
\hline $\begin{array}{l}\text { Few words are } \\
\text { contextualized. }\end{array}$ & 4 & 4 & 3 & 4 & 3 & 4 & 4 & 4 & 3 & 3 & 3.6 \\
\hline $\begin{array}{l}\text { Few vocabulary is } \\
\text { presented in a variety of } \\
\text { ways. }\end{array}$ & 3 & 4 & 3 & 1 & 2 & 3 & 3 & 2 & 2 & 1 & 2.4 \\
\hline $\begin{array}{l}\text { The topical nature of the } \\
\text { vocabulary exercises is } \\
\text { often meaningful to the } \\
\text { students. }\end{array}$ & 2 & 3 & 2 & 1 & 2 & 2 & 3 & 2 & 3 & 3 & 2.3 \\
\hline $\begin{array}{l}\text { Few lexical items appear } \\
\text { in each unit. }\end{array}$ & 2 & 3 & 2 & 3 & 3 & 2 & 3 & 3 & 3 & 3 & 2.7 \\
\hline $\begin{array}{l}\text { There is specific method } \\
\text { to teach new vocabulary. }\end{array}$ & 3 & 2 & 3 & 2 & 3 & 1 & 3 & 2 & 2 & 1 & 2.2 \\
\hline $\begin{array}{l}\text { The sentences and } \\
\text { examples that define new } \\
\text { vocabulary use words that } \\
\text { are known by learners. }\end{array}$ & 3 & 3 & 4 & 3 & 4 & 2 & 3 & 2 & 2 & 3 & 2.9 \\
\hline $\begin{array}{l}\text { There is an index of new } \\
\text { vocabulary at the end of } \\
\text { the textbook. }\end{array}$ & 1 & 2 & 1 & 1 & 2 & 1 & 1 & 1 & 1 & 1 & 1.0 \\
\hline TOTAL & 32 & 33 & 31 & 28 & 33 & 26 & 30 & 26 & 25 & 28 & \\
\hline
\end{tabular}

1. The Load of New Words

With an average of 2.3, the majority of the evaluators concluded that the textbook's new vocabulary part is somewhat beneficial for students. Evaluators 1, 2, 3, 4, and 5 ranked three for the new words introduces in each lesson, whereas evaluators 6,7 , and 10 ranked two and evaluators 8 and 9 ranked 1. Evaluators 1, 2, 3, 4, and 5 stated that a load of new words in each session is somewhat beneficial to students' fluency levels, but evaluators 6, 7, 8, 9, and 10 declared that the load is of poor appropriateness given the students' level.

Evaluators 1,2,3,4 and 5 were from suburban schools and they stated that the load of the new vocabulary were suitable with their students' level of proficiency. Evaluators $6,7,8,9$ and 10 were from urban school and they were unhappy with the load of the new vocabulary as they said that the new words were insufficient and easy for their students. Evaluators 8 and 9 commented that the load of new words were low useful as their students were familiar with most of the words and it was not challenging for their students.

2. Balance of Simple and Complex Words 
With a mean of 2.3, evaluators rated the textbook's basic and difficult terms as reasonably balanced. The textbook has a decent mix of basic and complicated vocabulary, according to evaluators $1,2,3,4$, and 5. Evaluators 6,7 , and 10 thought there was a good mix of simple and complicated terms, but evaluators 8 and 9 said there was an inadequate balance of simple and complex words.

\section{Distribution of Vocabulary Load Across each Chapter}

All of the evaluators felt that the word load was evenly distributed across each chapter. They appeared satisfied with the placement of new vocabulary items because they believed students would learn and utilise the terms well in each chapter. The vocabulary load in each chapter is appropriate for the pupils' level.

Indeed, one of the most crucial barriers to ESL readers' content understanding is a lack of relevant word knowledge; hence, vocabulary load is a strong indicator of text difficulty. Similarly, Haynes and Baker (1993) proposed that the most critical disadvantage for $L 2$ readers is a lack of English vocabulary awareness rather than a lack of reading comprehension abilities.

\section{Repetition of New Words for Delayed Recall}

Evaluators agreed that the repetition of new words was very useful. The words were used repeatedly in the textbook across the chapter. Students can use the words frequently and this will help students to understand the usage of the words better. Exposure to new words regularly and recurrently is much more crucial for beginners than it is for more experienced learners (Zahar et al., 2001). The textbook had fulfilled the process of retrieval and creative use. Evaluator 5 commented that the words in the textbook were used in context of the learning and this had helped her students to understand and use the words with correct context. There were recycling exercises and activities for the students to revise and use the new words. Thus, this helps students to remember the words better and confidence to use the words in their work.

\section{Contextualisation of New Words}

All of the evaluators agreed that the new words are very highly contextualised. There are few exercises for those new words introduced in the text. Students can guess the meaning of the words from the passage and pictures given. The activities help students grasp the words since their brains are engaged when they guess the appropriate words for the meaning rather than simply reading the meaning supplied.

There are also exercises that students need to find the meaning in the dictionary. This helps students to polish their dictionary skills. Dictionaries are a form of text that may be found in the educational domain, according to the CEFR. If reading abilities include the capacity to read and understand a variety of texts, including dictionaries, then guidance on how to read and process information in dictionaries should be included in the reading skills descriptors (Campoy-Cubillo, 2015).

\section{Presentation of New Vocabulary}

The introduction of new vocabulary in the textbook was reasonably satisfactory to the evaluators. Evaluator 4 and 10 ranked the presentation of new vocabulary as poor. Both of the evaluators mentioned that the meaning of new vocabulary is not given directly. Students need to find the meaning through the passage or in the dictionary. This will waste time as in 
each chapter there are many new words to introduce to students. Even though the new vocabulary is highlighted, it does not give direct meaning to the words. Students need to go through some exercises for them to guess the meaning of the words that match with the words in the text. It seems that for each text in the chapter, the new vocabulary is taught in the same strategies and techniques. An excellent textbook should have a range of methods for presenting new terms and activities to ignite the learners' interest in acquiring vocabulary. Kalthoum (2011) stated that a good textbook should have activities that manifest in many ways and cover the entire spectrum of linguistic abilities.

\section{Topical Nature of the Vocabulary Exercises}

The topical nature of the exercises is being ranked as moderate by the evaluators. 5 of the evaluators were satisfied whereas one evaluator was not satisfied with the topical nature of the vocabulary exercises. Most of the exercises and activities in the textbook are too simple for high achievers, while others are too challenging for low achievers. Overachievers may find the workouts to be too simple and uninspiring. On the other hand, the illustrations and graphics in the textbook contribute to sparking students' interest in reading and using the textbook.

\section{New Lexical Items}

Most evaluators ranked the new lexical item as good and only 3 evaluators satisfied with it. The majority of evaluators stated that the current lexical items in the textbook are not introduced in each chapter and it was not burdening the students to learn the new lexical. Students can take time to understand the new lexical items at their own pace throughout the chapter.

\section{Specific Method in Teaching New Vocabulary}

Evaluators 6 and 10 said that there is no specific method to teach new vocabulary in the textbook. Evaluators 2,4,8 and 9 ranked this criteria 2 and 4 evaluators ranked this criteria 3. The evaluators all concluded that the textbook lacked a defined approach for teaching new terms. The new vocabulary is frequently taught in a similar manner. Students must be taught a range of vocabulary acquisition techniques as well as the benefits and disadvantages of each vocabulary learning strategy (Al-Khresheh \& Al-Ruwaili, 2020). This might help students in determining the efficacy and usefulness of each technique and modifying them accordingly to fit their personal convenience and skill set. Thus, it is the teachers responsibility to introduce a variety of vocabulary learning strategies so that students will not feel bored learning new words.

\section{Definition of New Vocabulary}

Evaluators 1, 2, 4, 7 and 10 felt that the sentences and examples that define new vocabulary use words that are known by learners as good and evaluators 3 and 5 ranked as 4 that means excellent. Meanwhile, evaluators 6,8 and 9 were satisfied with the way the definition of the new vocabulary was presented. Even though most of the terms are simple to grasp, it depends on the students' vocabulary ability. Some terms may be unfamiliar to students with limited understanding of vocabulary learning. In this instance, teachers must explain the significance of the new terminology to their students. Teachers might also seek alternate approaches to teach new terminology to their students to achieve the textbook's objectives. 
11. Index of New Vocabulary

Eight of the evaluators agreed that there is no index of new vocabulary at the end of the textbook. There is an index of new vocabulary at the introduction of the textbook but it does not cover all the new words presented in the textbook. The index does not help the teacher to have some insights of the difficulty level of the new words. Whilst preparing for their lesson planning, teachers are given the additional duty to identify new words. It is also a waste of time to search for pages that include new vocabulary.

\section{Overall Evaluation}

Table 3. Overall results of the evaluation of the presentation of new vocabulary items in Malaysian year five English language textbook.

\begin{tabular}{|l|l|l|}
\hline Evaluator & $\begin{array}{l}\text { Total score } \\
\text { (Items 1- } \\
11)\end{array}$ & $\begin{array}{l}\text { Mean } \\
\text { Score }\end{array}$ \\
\hline 1 & 32 & 2.91 \\
\hline 2 & 33 & 3.0 \\
\hline 3 & 31 & 2.82 \\
\hline 4 & 28 & 2.55 \\
\hline 5 & 33 & 3.0 \\
\hline 6 & 26 & 2.36 \\
\hline 7 & 30 & 2.72 \\
\hline 8 & 26 & 2.36 \\
\hline 9 & 25 & 2.27 \\
\hline 10 & 28 & 2.55 \\
\hline Average & 29.2 & 2.66 \\
\hline
\end{tabular}

Key : 0.00-0.80 (Negligible usefulness), 0.81-1.60 (Low usefulness), 1.61-2.80 (Moderate usefulness), 2.81-3.60 (High usefulness), and 3.62-4.00 (Very high usefulness)

Table 3 displays the overall results of each evaluator's evaluation on the presentation of new vocabulary items in the textbook. The aggregate findings reflect how the evaluators assessed the textbook regarding how new language was presented in the textbook.

Evaluators 4, 6, 7, 8, 9, and 10 assessed the overall items of the presentation of new vocabulary in the textbook as somewhat beneficial for students based on the checklist for the elements of the presentation of new vocabulary scores interpretation guide in Appendix 1. The overall items were judged as extremely valuable by evaluators 1, 2, 3, and 5 .

As can be seen, evaluators from suburban schools (evaluators 1, 2, 3, and 5) evaluated the presentation of new vocabulary items in the Year 5 English language textbook as extremely beneficial to students' successful learning. The majority of them assigned ratings of 2 (low), 3 (moderate), and 4 to the criterion (high). They were pleased with how the new terminology was presented in the textbook. 
Meanwhile, urban school evaluators (evaluators 6, 7, 8, 9, and 10) found the presentation of new vocabulary items in the Year 5 English language textbook to be fairly beneficial for students' successful learning. The majority of these evaluators' scores were 1, 2 (low), and 3, respectively (moderate). They virtually gave the presentation of new vocabulary items in the textbook a high rating.

Evaluators $6,7,8,9$, and 10 did not find the vocabulary to be particularly useful. As a consequence, this demonstrated that the school demographic affected the research's conclusions and findings. They rated the textbook's introduction of new vocabulary items as almost moderate.

Evaluators from urban schools are dissatisfied with the textbook's presentation of new terminology. They believed that the new vocabulary was simple for their students and that there was no difficulty in acquiring the new words. Teachers from suburban schools, on the other hand, appeared to be pleased with the introduction of new vocabulary in the textbook. Students were compelled to learn new terms and were challenged to do so. However, teachers appeared to be having difficulty introducing the new vocabulary to their students.

\section{Implications and Conclusion}

This study attempts to explore teachers' evaluation on the presentation of new vocabulary in English Plus 1 for Year 5 primary school in Malaysia. The findings from the survey checklist revealed that all the evaluators agreed that new words presented in the textbook are appropriately presented. The evaluators think that the distribution of the new words are relevant for Malaysian Year 5 pupils as the arrangements of the new vocabulary are presented in the contextualised way so that pupils can understand better the meaning and the usage of the words. Although the evaluators praised the way the new words presented in the textbook but the evaluators also commented that there is no specific method that they can use as a guide for them to introduce the new vocabulary to the pupils especially when the teacher did not have the knowledge to explain the abstract word in the pupils' first language. This is because some of the abstract words are not presented in the topical nature where the pupils can use the words in their daily life. Hence, it makes the lesson become less meaningful and unattractive. Thus, the evaluators hope that the ministry of education can come out with a guidebook of how to introduce the new vocabulary to the pupils especially for teachers that teach in the vernacular schools. The guide book can somehow help to give ideas to teachers to varied the lesson and to introduce the new words to the pupils. It also help teachers saving time to prepare the lesson introducing the new words and replacing the time with planning activities and worksheets that are enjoyable for the pupils. Other than that, teachers also can utilise their own resources such as newspapers, magazines, music, and movies to create a pleasant and interesting teaching-learning environment in the classroom. Teachers can also use modern technology to deliver a lesson, such as Canva, Google Classroom, Quizziz or games so that students will be interested in learning new vocabulary.

Based on the outcomes of the study, it is feasible to conclude that the English Plus 1 may still need improvement regarding the presentation of new vocabulary items. The outcomes of the study will most likely be useful to English language teachers. 
The study does have certain drawbacks. It was just an attempt by a few English teachers to evaluate the presentation of new vocabulary items in English Plus 1, a Year 5 English language textbook used in elementary schools. The evaluators for this study are just 10 Malaysian Primary English teachers. As a result, the findings cannot be applied to the viewpoints of all Malaysian instructors. Furthermore, the scope of this study was limited to the student book. Because of the limitations of the current study, more research using different methodologies is necessary to evaluate the textbook's vocabulary pieces.

For future research, a similar research can be conducted for different year as the syllabus in Malaysia is changing to CEFR from 2018 until 2022. Given the importance of vocabulary acquisition in the development of the four learning skills, additional research can be performed by using or modifying additional instruments, such as checklists or questionnaires, that include various lexical requirements to know the suitability of the new words in each year primary English textbook and help the teachers to know what they will expect to teach the new vocabulary. This will surely change the teachers' perspective in introducing the new vocabulary especially in vernacular school.

Learning new words is critical since a lack of vocabulary knowledge can impair all four language skills: hearing, speaking, reading, and writing. The addition of new terms to the textbook should be acceptable and beneficial for the students' requirements. The goal of this study was to assess how new vocabulary items were presented in Malaysia's Year Five English language textbook. Ten Year Five English teachers used the evaluation checklist for new vocabulary items to evaluate the vocabulary items in the textbook.

There were five evaluators from urban Chinese Primary School and other five evaluators suburban Chinese Primary School. The study's findings indicated that highly urban school evaluators typically believed the new language was unsuitable for the students. On the other hand, the suburban school evaluators appeared to be somewhat happy with the vocabulary pieces in the textbook. None of the evaluators thought the introduction of new vocabulary items was very appropriate.

The evaluators noted that the suitability of the items for the vocabulary load of new words in each chapter is dependent on the students' English language competence. Evaluators 1, 2, 3, 4 , and 5 evaluated the item as fairly suitable to students' linguistic levels, whereas evaluators $6,7,8,9$, and 10 ranked it as less appropriate to students' levels. Furthermore, many of the new terms are not included in the wordlist supplied in the English Year 5 curriculum standards. The first five evaluators evaluated the balance of basic and complicated terms as moderate, but evaluators 6 to 10 were less happy. The distribution of vocabulary load over the whole book was likewise assessed as moderate since the overall material of the textbook meets the students' context of the difficulty.

Furthermore, there was enough repetition of new phrases throughout the text to assist with delayed recollection. The evaluators believed that the textbook is on the right track to follow the process of retrieval and creative usage since there are recycling activities or assignments for the students to revisit the new terms. Students should revisit and reuse new vocabulary as often as possible to expand their vocabulary range and to be able to recall and use such terms for long-term retention. The vocabulary was rated as average in terms of 
contextualization of new words. Students should be provided exercises in each class to help them understand meaning from context. However, these tasks are insufficient to assist students in developing and expanding their vocabulary knowledge. It was also discovered that, excluding two evaluators who thought the presentation of the new language in the textbook was insufficient, the evaluators were satisfied with the presentation of the new vocabulary in the textbook. The majority of them agreed that the new vocabulary should be introduced in a variety of methods to stimulate learners' interest in acquiring it.

The evaluators noticed that some of the textbook's exercises and activities are extremely simple for high scorers and overly challenging for low achievers. Overachievers may find the routines dull and overly straightforward. They also claimed that the relevance of the vocabulary activities should help pupils develop their critical thinking skills. The majority of evaluators thought that new vocabulary items were presented in each part of the textbook. Teachers should investigate the most effective methods for teaching each lexical item to their pupils.

Furthermore, there was no specific instruction in the textbook for introducing the new terminology. The new vocabulary was taught in the same way in each unit. The evaluators thought that the language and images used to convey the new vocabulary used terms that students were acquainted with. The authors used short sentences to convey the new vocabulary in the textbook in order to offer students a better understanding of it. Finally, some evaluators expressed dissatisfaction with the indexation of new vocabulary, which they felt should have been presented towards the end of the textbook. It assigned teachers the extra responsibility of recognising the new language in the textbook. The textbook was found to meet the requirements for a good English textbook, notably in terms of vocabulary.

Based on the outcomes of the study, it is feasible to conclude that the English Plus 1 may still need improvement regarding the presentation of new vocabulary items. The outcomes of the study will most likely be useful to English language teachers.

\section{References}

Abdelwahab, M. M. (2013). Developing an English Language Textbook Evaluative Checklist. JOSR Journal of Research \& Method in Education, 1(3), 55-70.

Abdul Rahim, H., \& Daghigh, J. A. (2020). Locally-developed vs. Global Textbooks: An Evaluation of Cultural Content in Textbooks Used in ELT in Malaysia. Asian Englishes, 22(3), 317-331.

Abhar, N. (2017). Evaluating 7th Grade English Textbook Based on Ellis Evaluation Frameworka. Studies in Literature and Language, 15(2), 32-37.

Al-Khresheh, M. H., \& Al-Ruwaili, S. F. (2020). An Exploratory Study into Vocabulary Learning Strategies Used by Saudi EFL learners. Journal of History Culture and Art Research, 9(2), 288-302.

Campoy-Cubillo, M. C. (2015). Assessing dictionary skills. Lexicography, 2(1), 119-141.

Garinger, D. (2001). Textbook evaluation. TEFL Web Journal. Retrieved from http://www.teflwebj.org/v1n1/garinger.html

Goh, Y. T., \& Abdul Aziz, A. (2020). Using PULSE 2 to teach and assess Malaysian pupils' speaking skill. International Journal of Publications and Social Studies, 5(1), 55-68. 
Haynes, M., \& Baker, I. (1993). American and Chinese readers learning from lexical familiarization in English text. In T. Huckin, M. Haynes, \& J. Coady (Eds.), Second Language Reading and Vocabulary Learning (pp. 130-152). Norwood, NJ: Ablex.

Hemmi, K., Krzywacki, H., \& Liljekvist, Y. (2019). Challenging traditional classroom practices: Swedish teachers' interplay with Finnish curriculum materials. Journal of Curriculum Studies, 51(3), 342-361.

Hussin, N. I. S. M., Nimehchisalem, V., Kalajahi, S. A. R., \& Yunus, N. (2016). Evaluating the presentation of new vocabulary items in Malaysian form three English language textbook. Malaysian Journal of Languages and Linguistics (MJLL), 5(1), 60-78.

James, P. R., \& Aziz, A. A. (2020). Perceptions and Expectancies of Malaysian Students on Cultural Elements in Foreign Textbooks. International Journal of Academic Research in Business and Social Sciences, 10(4).

Kalthoum, R. M. S. (2011). The evaluation of English textbook in the 3rd year secondary school in Libya. (Unpublished master's thesis). Universiti Putra Malaysia, Serdang, Malaysia.

Littlejohn, A. (1998). The analysis of language teaching materials: Inside the Trojan horse. In Tomlinson, B. (Ed.), Materials development in language teaching (pp.190-216) Cambridge: Cambridge University Press.

Litz, D. R. A. (2005). Textbook evaluation and ELT management: A South Korean case study. Asian EFL Journal. Retrieved November 12, 2012, from http://www.asianefljournal.com/Litz_thesis.pdf

Lynch, B. K. (1996). Language program evaluation: Theory \& practice. Cambridge: Cambridge University Press.

Nimehchisalem, V., \& Mukundan, J. (2015). Refinement of the English Language Teaching Textbook Evaluation Checklist. Pertanika Journal of Social Sciences \& Humanities, 23(4).

Razmjoo, S. A. (2010). Developing a textbook evaluation scheme for the expanding circle. Iranian Journal of Applied Language Studies, 2(1), 121- 136.

Riazi, A. M. (2003). "What Textbook Evaluation Schemes Tel Us? A study of the textbook evaluation schemes of three decades", in W. A. Renanda. (ed.), Methodology and Materials Design in Language Teaching, Singapore (pp. 52-68). SEAMEO Regional Center.

Richards, J. C. (2001). Curriculum development in language teaching. Cambridge: Cambridge University Press. 28. Sheldon, L. E. (1988). Evaluating ELT textbooks and materials. ELT Journal, 42, 237-246. http://dx.doi.org/10.1093/elt/42.4.237

Sani, R. (2018). Building capacity to increase English proficiency. News Straits Times.

Schmitt, N., Schmitt, D., \& Clapham, C. (2001). Developing and exploring the behaviour of two new versions of the Vocabulary Levels Test. Language testing, 18(1), 55-88.

Shak, M. S. Y., Malik, N. A., Hasni, N. A., \& Tahir, M. H. M. (2021). Revisiting PULSE 2 Textbook after Three Years: Have Teachers Changed Their Mind?. Malaysian Journal of Social Sciences and Humanities (MJSSH), 6(5), 177-189.

Sun, Y., Yen Dang, T.N., Vocabulary in high-school EFL textbooks: Texts and learner knowledge, System (2020), doi: https://doi.org/10.1016/j.system.2020.102279.

Takal, G. M., Planisamay, T., Gani, N. A. B. I., Peter, C. V., \& Rahmat, A. (2021). An Evaluation of 'Get Smart'English Language Textbook from the Perspectives of English Teachers. Aksara: Jurnal IImu Pendidikan Nonformal, 7(2), 727-746.

Thornbury, S. (2006). How to teach vocabulary. Pearson Education India.

Tomlinson, B. (Ed.). (2011). Materials development in language teaching. Ernst Klett Sprachen. 
Vavrus, F., \& Salema, V. (2013). Working lives of teachers: Social and material constraints. In Teaching in tension (pp. 75-92). Brill Sense.

Webb, S., \& Nation, I. S. P. (2017). How vocabulary is learned. Oxford: Oxford University Press. Zahar, R., Cobb, T., \& Spada, N. (2001). Acquiring vocabulary through reading: Effects of frequency and contextual richness. Canadian Modern Language Review, 57(4), 541-572. 
INTERNATIONAL JOURNAL OF ACADEMIC RESEARCH IN BUSINESS AND SOCIAL SCIENCES Vol. 11, No. 12, 2021, E-ISSN: 2222-6990 @ 2021 HRMARS

\section{APPENDIX 1- QUESTIONNAIRE}

\section{CHECKLIST FOR EVALUATING NEW VOCABULARY PRESENTATION IN YEAR 5 ENGLISH TEXTBOOK}

Teacher's Background
Age
25-30 years old
31-36 years old
37-42 years old
43-48 years old
49-54 years old
55-60 years old
Level of education
Diploma
Degree
Master
PhD

The topical nature of the vocabulary exercises is often meaningful to the students.
0: Totally lacking
1: Poor
2: Satisfactory
3: Good
4: Excellent

New lexical items (single word, a part of a word, or a chain of words that forms the basic elements of a language) appear in each unit.
0: Totally lacking
1: Poor
2: Satisfactory
3: Good
4: Excellent

There is specific method to teach new vocabulary.
0 : Totally lacking
1: Poor
2: Satisfactory
3: Good
4: Excellent

The sentences and examples that define new vocabulary use words that are known by learners.

0 : Totally lacking

1: Poor

2: Satisfactory

3: Good
Good distribution of vocabulary load across each chapter.
0: Totally lacking
1: Poor
2: Satisfactory
3: Good
4: Excellent

New words are contextualised.
0: Totally lacking
1: Poor
2: Satisfactory
3: Good
4: Excellent

New words are repeated across the book for delayed recall (ability to recall specific information after a period of rest or distraction from that information).

o: Totally lacking

1: Poor

2: Satisfactory

3: Good

4: Excellent

Visuals have been used effectively to present the new vocabulary.

0: Totally lacking

1: Poor

2: Satisfactory

3: Good

4: Excellent 